\title{
8-OHDPAT-Induced Disruption of Prepulse Inhibition in Rats is Attenuated by Prolonged Corticosterone Treatment
}

\author{
Anna Czyrak*,', Marzena Maćkowiak', Agnieszka Chocyk', Katarzyna Fijał', Anna Gądek-Michalska', and \\ Krzysztof Wędzony' \\ Institute of Pharmacology, Polish Academy of Sciences, Kraków, Poland
}

\begin{abstract}
The present study investigated the impact of acute and repeated administrations of corticosterone ( $10 \mathrm{mg} / \mathrm{kg}$, twice daily, for 7 days $)$ on serotonin $(5-\mathrm{HT})_{\text {IA }}$ receptor function, density and expression. The effect on $5-\mathrm{HT}_{\text {IA }}$ receptor function was assayed in rats by assessing the corticosterone-induced modulation of disruption of prepulse inhibition (PPI) of acoustic startle response induced by 8-OHDPAT, a 5-HTIA receptor agonist. Our experiments revealed that repeated but not acute treatment with corticosterone attenuated the 8OHDPAT-evoked disruption of PPI without having any effect on PPI or startle amplitude alone. Chronic corticosterone treatment modulated also the neuronal activity of serotonergic pathways in the brain decreasing the level of 5-HIAA in the raphe nuclei and increasing both 5-HT and 5-HIAA levels in the hippocampus. Nevertheless, the effects of 8-OHDPAT on 5-HT metabolism were not changed by corticosterone. However, $5-\mathrm{HT}_{\text {IA }}$ receptor binding in the ventral hippocampus and entorhinal cortex (EC) but not in the raphe nuclei was decreased after chronic corticosterone treatment. It is concluded that chronically elevated corticosterone level is capable of inducing functional desensitization of 5- $\mathrm{HT}$ IA receptors which is paralleled by decreases in the 5- $\mathrm{HT}_{\text {IA }}$ receptor binding in the ventral hippocampus and EC, the brain structures shown to be engaged in the regulation of PPI. Alterations in 5-HT IA receptors may be one of important mechanisms by which glucocorticoids/stress influence various psychiatric conditions.

Neuropsychopharmacology (2003) 28, I300-1310, advance online publication, 9 April 2003; doi:I0.1038/sj.npp. I300। 65
\end{abstract}

Keywords: corticosterone; entorhinal cortex; 5-HT; 5-HT IA receptor; raphe nuclei; sensorimotor gating

\section{INTRODUCTION}

Prepulse inhibition (PPI) of the acoustic startle response can be measured in human subjects as well as in laboratory animals (Geyer et al, 2001; Swerdlow et al, 2001a). It has recently gained considerable attention as an animal model of gating deficits in schizophrenia (Geyer et al, 1990; Braff et al, 1992, 2001). In this paradigm, brief presentation of a nonstartling prepulse stimulus, shortly prior to presentation of a startling stimulus, results in an inhibition of the startle response. As mentioned above, the inhibition of such response is disrupted in schizophrenic patients, and it can be altered in laboratory rats by manipulations that change brain neurotransmission. Among drugs that evoke strong impairments of PPI are substances affecting glutamatergic, dopaminergic and 5-HT (serotonergic) neurotransmission (for a review see Koch, 1999; Geyer et al, 2001). In addition to pharmacological manipulations, environmental factors

*Correspondence: Dr A Czyrak, Institute of Pharmacology, Polish Academy of Sciences, 31-343 Kraków, Smętna Street 12, Poland, Tel: +48 12662 3253, Fax: + 48126374500 ,

E-mail: czyrak@if-pan.krakow.pl

Received 26 September 2002; revised 19 December 2002; accepted I 5 January 2003

Online publication: 22 January 2003 at http://www.acnp.org/citations/ Npp0 I2203467/default.pdf have also been shown to disrupt PPI (see Geyer et al, 2001 for a review). It was evidenced that in normal adult human subjects stress was capable of diminishing PPI (Grillon and Davis, 1997), while corticotropin releasing factor (CRF), a neurotransmitter that is released during stress, diminished PPI in rats (Conti et al, 2002). Moreover, rearing rats in isolation, maternal separation and chronic stress have also been shown to attenuate PPI, although negative results have been reported as well (Geyer et al, 1993; Ellenbroek et al, 1998; Faraday et al, 1999; Sipos et al, 2000; Geyer et al, 2001, Weiss and Feldon, 2001). Nevertheless, the results cited above raised the question about the role of stress and stress hormones in the exacerbation of symptoms of schizophrenia (Walker and Diforio, 1997; Walder et al, 2000).

Corticosterone is the main glucocorticosteroid hormone produced by the rat adrenal glands in response to stress. The released corticosterone readily enters the central nervous system (McEwen et al, 1968), where it binds to two types of intracellular receptors (de Kloet et al, 1990): high affinity mineralocorticoid receptors (MR) and lower affinity glucocorticoid receptors (GR). In the rat brain, MR receptors are present mainly in the hippocampus, in contrast to GR receptors, which have much more widespread distribution (Harfstrand et al, 1986; de Kloet et al, 1990; Ahima et al, 1992), being localized in many areas 
important for PPI control (Sipes and Geyer, 1995; Fendt et al, 2001; Fletcher et al, 2001; Swerdlow et al, 2001a,b), such as the hippocampus, cerebral cortex, amygdala, mesolimbic areas, nuclei of monoaminergic neurons and brain stem nuclei. This suggests that corticosterone may have direct effects on PPI or can act via modulation of brain neurotransmission.

Changes in glucocorticoid level were shown to influence potently the 5-HT neurotransmission, especially at the level of $5-\mathrm{HT}_{1 \mathrm{~A}}$ receptors in the hippocampus. As evidenced by electrophysiological studies, both adrenalectomy (ADX) and corticosterone treatment modulated responses to 5$\mathrm{HT}_{1 \mathrm{~A}}$ receptor stimulation in the hippocampal neurons (Joels and de Kloet, 1992; Karten et al, 1999; Mueller and Beck, 2000; Czyrak et al, 2002). The ADX animals showed rapid increase in the synthesis of $5-\mathrm{HT}_{1 \mathrm{~A}}$ receptor mRNA, and an increase in $5-\mathrm{HT}_{1 \mathrm{~A}}$ receptor binding in the hippocampus, and both these effects were prevented by low concentrations of corticosterone (Mendelson and McEwen, 1992a; Chalmers et al, 1994; Kuroda et al, 1994; Tejani-Butt and Labow, 1994). All these studies show that the $5-\mathrm{HT}_{1 \mathrm{~A}}$ receptors (at least in the hippocampus) are under glucocorticoids control. They also suggest that in psychiatric pathologies with characteristic elevation of adrenocorticoid levels, the ability of these hormones to change $5-\mathrm{HT}_{1 \mathrm{~A}}$ receptors may be included among the factors that modulate clinical symptoms.

Although schizophrenia and coexisting cognitive deficits are traditionally linked with dysfunction of dopamine and 5- $\mathrm{HT}_{2 \mathrm{~A}}$ receptors (for review see Harrison, 1999), recent clinical data suggest also the involvement of $5-\mathrm{HT}_{1 \mathrm{~A}}$ receptors (Burnet et al, 1996; Bantick et al, 2001). Moreover, experimental data show that direct agonists of $5-\mathrm{HT}_{1 \mathrm{~A}}$ receptors are able to disrupt PPI (Rigdon and Weatherspoon, 1992; Sipes and Geyer, 1994, 1995; Fletcher et al, 2001; Prinssen et al, 2002). The role of $5-\mathrm{HT}_{1 \mathrm{~A}}$ receptors in modulation of sensorimotor gating mechanisms is further supported by the fact that disturbances in PPI induced by psychotomimetic substances (such as MK-801) are attenuated by $5-\mathrm{HT}_{1 \mathrm{~A}}$ receptor antagonists (Wedzony et al, 2000).

Above arguments prompted us to investigate whether the treatment with corticosterone, the main glucocorticoid hormone in rats, would be able to influence process of sensorimotor gating measured as PPI. Further, our study evaluated the effect of corticosterone on 8-OHDPAT-evoked disruption of PPI, on the assumption that the results of such experiment would reflect the effect of corticosterone on 5$\mathrm{HT}_{1 \mathrm{~A}}$ receptor-mediated cognitive dysfunction expressed as disruption of sensorimotor gating. In the light of the hypothesis of Sipes and Geyer (1995) that the disruptive effects of 8-OHDPAT on PPI were (at least in part) due to its ability to decrease serotonergic neuronal activity, the impact of corticosterone on the level of 5-HT and its metabolite 5-HIAA in vehicle and 8-OHDPAT-treated rats was also assessed. Finally we examined whether the applied regimen of corticosterone treatment has an impact on $5-\mathrm{HT}_{1 \mathrm{~A}}$ receptors in the brain regions, which have been shown to be implicated in the regulation of PPI. For this purpose, $5-\mathrm{HT}_{1 \mathrm{~A}}$ receptor $\mathrm{mRNA}$ and the binding of $\left[{ }^{3} \mathrm{H}\right] 8$-OHDPAT to those receptors were analyzed in the dorsal and ventral part of hippocampus, entorhinal cortex (EC) and raphe nuclei.

\section{MATERIALS AND METHODS}

\section{Animals and Drug Treatments}

Male Wistar rats (250-300 g) were used in all the experiments. The animals were housed in groups of six under controlled conditions ( $12 \mathrm{~h}$ light/dark cycle, $22 \pm 2{ }^{\circ} \mathrm{C}$ ). The rats were allowed at least one week habituation to the animal room, and had free access to a standard laboratory diet and tap water. Corticosterone-21-acetate (Sigma, St Louis, MO) was prepared as a suspension in $1 \%$ Tween 80 and was administered at a dose of $10 \mathrm{mg} / \mathrm{kg}$ s.c., acutely (single dose), or repeatedly (twice a day for 7 days). All the experiments were performed (or rats were decapitated) $2 \mathrm{~h}$ (acute treatment), or 2 and $24 \mathrm{~h}$ (repeated treatment) after the last injection of corticosterone or vehicle. The experimental protocols were approved by the Committee for Laboratory Animal Welfare and Ethics of the Institute of Pharmacology, Polish Academy of Sciences in Kraków and met the criteria of the International Council for Laboratory Animals, Guide for the Care and Use of Laboratory Animals.

\section{Measurement of Serum Corticosterone}

The animals were decapitated and their blood samples were collected from the trunk to determine serum corticosterone levels. Corticosterone levels were measured by a radioimmunoassay (Przegalinski et al, 1992), using rabbit antiserum raised against corticosterone-21-thyroglobulin (Sigma, St Louis, MO) as an antigen. The antiserum showed a very low cross-reactivity with other major steroids. The assay sensitivity was $10 \mathrm{pg} /$ tube.

\section{FUNCTIONAL STUDIES}

\section{PPI of Acoustic Startle Response}

The apparatus for measuring of the startle response was placed in a sound-proof cabinet, and consisted of three identical $(17 \times 30 \times 17 \mathrm{~cm})$, transparent Plexiglas cages (Columbus Instruments, $\mathrm{OH}$ ), which were equipped with a moveable platform floor attached to a sensor recording vertical movements of the floor (Wedzony et al, 1994, 2000). A startle reflex was evoked by acoustic stimuli delivered from a loudspeaker suspended above the cage and connected to an acoustic generator. The transient force resulting from movements of the platform, evoked by the startle reaction of rat to acoustic stimuli, was recorded with a PC computer during a recording window of $200 \mathrm{~ms}$, measured from the onset of the acoustic stimuli, and was then digitalized and stored in the computer for further evaluation. The amplitude of the startle response was defined as a difference between the maximum force detected during a recording window and the force measured immediately before the stimulus onset (expressed in arbitrary units). The threshold level was set at $10 \mathrm{~g}$, so that responses exceeding a force of $10 \mathrm{~g}$ would activate the automatic peak detection software. The threshold of $10 \mathrm{~g}$ allowed a correct evaluation of the maximum response in all the tested animals. The amplitudes were averaged for each individual animal, separately for both types of trials (stimulus alone or stimulus preceded by prepulse). 
Prior to drug administration, the animals were exposed to a single startle session (identical to that described below). The purpose of that procedure was to familiarize the animals with the test cages and, consequently, to produce a more stable baseline of startle/PPI responding and secondly, to make sure that the animals were allocated to the balanced groups in terms of equivalent startle amplitude and PPI. On a test day, the rats were injected with the vehicle or drug, and after an appropriate time they were placed into the testing cages. The experimental session consisted of a 5-min habituation to the $65 \mathrm{~dB}$ background white noise (continuous throughout the session), followed by a test session. During the test session, each rat was confronted with two types of trials: (1) $120 \mathrm{~dB}, 40 \mathrm{~ms}$ pulse, (2) $75 \mathrm{~dB}, 20 \mathrm{~ms}$ prepulse followed $80 \mathrm{~ms}$ later by a $120 \mathrm{~dB}, 40 \mathrm{~ms}$ pulse (all pulses had $4000 \mathrm{~Hz}$ frequency). Each trial type was presented 20 times during the session with $20 \mathrm{~s}$ intertrial intervals. Thus, the session consisted of two blocks of 20 trials, with trial order arranged according to a Latin square design. The animals' responses to each trial type in each block were averaged out for every single animal and used for further calculations. The degree of PPI was shown as a percentage score (\%PPI) calculated as $([(\mathrm{P})-(\mathrm{PP}+\mathrm{P}) /$ $\mathrm{P}] \times 100)$ a difference between the amplitude of the pulse alone $(\mathrm{P})$ and the amplitude of the prepulse + pulse trials $(\mathrm{PP}+\mathrm{P})$, divided by the amplitude of the pulse alone trials and multiplied by 100 (Wedzony et al, 1994). A high value of the calculated \%PPI indicated that the prepulse inhibited the response to a pulse stimulus, whereas a low value indicated weaker inhibition by prepulse.

8-OHDPAT $(0.2,1.25,5.0 \mathrm{mg} / \mathrm{kg}$ s.c.) was given $15 \mathrm{~min}$ before beginning of the test session. WAY $100135(2.5,5.0$, $20.0 \mathrm{mg} / \mathrm{kg}$ s.c.) was given $30 \mathrm{~min}$ before 8-OHDPAT; the last dose of corticosterone was administered 2 and $24 \mathrm{~h}$ before 8-OHDPAT. Independent groups of animals were used for all the drug treatments.

\section{Measurement of 5-HT and 5-HIAA Concentrations}

The rats treated chronically with corticosterone or respective vehicle were killed by decapitation $24 \mathrm{~h}$ after the last dose. One hour before decapitation, respective groups received 8 -OHDPAT $(1.25 \mathrm{mg} / \mathrm{kg}$ s.c.) or saline injection. The brains were quickly removed and parts of the brains containing raphe nuclei were cut into $1-\mathrm{mm}$ coronal slices using a Rodent Brain Matrix (Activational Systems Inc., Michigan) from which raphe nuclei were dissected with a punching tube $(0.5 \mathrm{~mm}$ in diameter) as described previously (Wedzony et al, 1997). The hippocampus was isolated from the rest of the brain. The tissue samples were stored at $-70^{\circ} \mathrm{C}$ until assay. On the day of assay, the tissue samples were homogenized in $0.1 \mathrm{M} \mathrm{HClO}_{4}$ containing $0.26 \mathrm{mM}$ ascorbic acid, centrifuged (14000 g), and filtered through $0.2 \mu \mathrm{m}$ cellulose membranes. To determine the 5-HT and 5HIAA levels, the $10 \mu \mathrm{l}$ sample aliquots were injected onto a HPLC column (ODS, Phase II, particle size $3 \mu \mathrm{m}, 3.2$ / $100 \mathrm{~mm}$; BAS). A standard HPLC technique (BAS 400, Bioanalytical Systems, USA) with an electrochemical detection (BAS- LC-4B detector with an oxidation potential of $0.65 \mathrm{~V}$ against $\mathrm{Ag} / \mathrm{AgCl}$ reference electrode and a glassycarbon working electrode TL5) was used. The mobile phase (flow rate $0.8 \mathrm{ml} / \mathrm{min}$ ) consisted of $0.06 \mathrm{M}$ citrate-phosphate buffer ( $\mathrm{pH}$ 3.5), $0.27 \mathrm{mM}$ EDTA, $0.32 \mathrm{mM}$ sodium octyl sulfonate and $2.4 \%$ methanol. The 5-HT and 5-HIAA levels were quantified by a peak area comparison with standards, run on the day of the analysis, using Inject software. A histological verification of brain areas was carried out in slices transferred into a phosphate buffer containing $4 \%$ paraformaldehyde.

\section{RECEPTOR STUDIES}

\section{Preparation of Brain Sections}

The rats were decapitated 2 or $24 \mathrm{~h}$ after the last vehicle or corticosterone injection, the brains were removed and rapidly cut into coronal blocks, containing the hippocampus or raphe nuclei with $\mathrm{EC}$, frozen by submersion in dryice cold isopentane and stored at $-70^{\circ} \mathrm{C}$ until sectioning. Coronal sections $(10 \mu \mathrm{m})$ were cut on a cryostat (Leica LC $3000)$, thaw-mounted onto subbed glass microscope slides and stored at $-20^{\circ} \mathrm{C}$.

\section{$5 \mathrm{HT}_{1 \mathrm{~A}}$ Receptor Autoradiography}

At the beginning, the sections were preincubated $(30 \mathrm{~min}$, room temperature) in $50 \mathrm{mM}$ Tris- $\mathrm{HCl}$ buffer $(\mathrm{pH} 7.4)$ containing (in $\mathrm{mM}$ ) $180 \mathrm{NaCl}, 5 \mathrm{KCl}, 2.5 \mathrm{CaCl}_{2}$, and 1.2 $\mathrm{MgCl}_{2}$. Binding assay was carried out (Wedzony et al, 1997) by incubating the sections for $60 \mathrm{~min}$ (room temperature) with $1.5 \mathrm{nM}\left[{ }^{3} \mathrm{H}\right] 8$-OHDPAT (Amersham, specific activity $137 \mathrm{mCi} / \mathrm{mmol}$ ) in the same $50 \mathrm{mM}$ Tris- $\mathrm{HCl}$ buffer supplemented with ascorbic acid $(10 \mathrm{mg} / 1 \mathrm{dl})$ and pargyline $(0.2 \mathrm{mg} / 1 \mathrm{dl})$. Nonspecific binding was determined in adjacent sections under the same conditions except for the presence of $5 \mu \mathrm{M} 5$-HT. After incubation the sections were rinsed, dried, and apposed to a Hyperfilm $-{ }^{3} \mathrm{H}$ (Amersham) along with a tritium standard $\left({ }^{3} \mathrm{H}\right.$-microscale, Amersham) in an X-ray cassette for 3 weeks at $4^{\circ} \mathrm{C}$. The films were then developed with D-19 Kodak developer. Autoradiographs were quantified by a computerized densitometry (Image Analyzing System, Image ProPlus, Media Cybernetics, USA). The measured light transmittance values were converted into a tissue equivalent radioactivity (with reference to standards), and thus to binding values (fmol/mg tissue, with reference to the specific activity) of the radiolabeled ligand. Values of the nonspecific binding were determined directly from film images of the sections incubated in the presence of the displacer 5-HT $(5 \mu \mathrm{M})$. Those values were averaged and subtracted from the total binding to obtain specific binding values. Anatomical regions were verified according to the Paxinos and Watson atlas (1998) in tissue sections stained with cresyl violet.

\section{In Situ Hybridization Histochemistry}

Prior to hybridization, the tissue sections were fixed in $0.01 \mathrm{M}$ phosphate-buffered saline ( $\mathrm{pH} 7.0$ ) containing $4 \%$ paraformaldehyde $\left(10 \mathrm{~min}, 0^{\circ} \mathrm{C}\right)$. The slides were then washed and acetylated with a mixture of $0.1 \mathrm{M}$ triethanolamine ( $\mathrm{pH} 8)$ and $0.25 \%$ acetic anhydride for $10 \mathrm{~min}$ and subsequently dehydrated in graded ethanol, defatted in chloroform, rinsed in graded ethanol and air-dried. For the in situ hybridization assay, a mixture of two 30-mer 
deoxyoligonucleotide probes (Genset., USA), corresponding to amino-acid sequences $175-184$ and 262-271 of the rat $5-\mathrm{HT}_{1 \mathrm{~A}}$ receptor, was used (Liao et al, 1993). A homology search (Fast GENBANK) showed no significant homology with any known protein. The probes were labeled with $\left[\alpha_{-}{ }^{35} \mathrm{~S}\right] \mathrm{dATP}$ (NEN, Belgium) using a terminal transferase (Boehringer-Mannheim, Germany), purified chromatographically (Micro Bio-Spin Chromatography columns, BioRad, USA $)$, and stored $\left(3 \times 10^{5} \mathrm{dpm} / \mu \mathrm{l}\right)$ at $-20^{\circ} \mathrm{C}$ until further use. The sections were hybridized with the $\left[{ }^{35} \mathrm{~S}\right] \mathrm{dATP}$-labeled probe $(100 \mu \mathrm{l} / \mathrm{slide})$, diluted to a final activity of about $2.45 \times 10^{5} \mathrm{dpm} / \mathrm{ml}$ in a hybridization buffer (50\% deionized formamide, $4 \times$ SSC, $25 \mathrm{mM}$ sodium phosphate, $1 \mathrm{mM}$ sodium pyrophosphate, $1 \times$ Denhardt's solution, $200 \mu \mathrm{g} / \mathrm{ml}$ salmon sperm DNA, $100 \mu \mathrm{g} / \mathrm{ml}$ polyadenylic acid, $10 \%$ dextran sulfate, $250 \mu \mathrm{g} / \mathrm{ml}$ yeast tRNA) for $20 \mathrm{~h}$ at $42^{\circ} \mathrm{C}$ in a humidified incubator (Wedzony et al, 2000). After incubation, the sections were rinsed in $1 \times \mathrm{SSC}$ (room temperature), washed 3 times in $1 \times \mathrm{SSC}$ at $55^{\circ} \mathrm{C}$ for $15 \mathrm{~min}$, then in $1 \times \mathrm{SSC}$ at room temperature for $30 \mathrm{~min}$, and rinsed finally in $0.1 \times$ SSC and in sterile water. After washes, the slides were dehydrated in graded ethanol, dried, and exposed to an X-ray film (Hyperfilm- $\beta_{\max }$ Amersham) for 20 days at $4{ }^{\circ} \mathrm{C}$ and processed with a D-19 Kodak developer. The specificity of the hybridization signal was confirmed by visualizing silver grains over individual cell bodies. To this end, the slides were immersed in a photographic emulsion (Kodak NBT 3 emulsion) and left in darkness for 12 weeks. After processing with D-19 Kodak developer they were counterstained with cresyl violet. The autoradiographs were analyzed using an image analysing system (SPOT-32 camera and Image ProPlus). For quantification, the mean optical density of a specific hybridization signal was measured in the regions of interest.

\section{DRUGS, DATA PRESENTATION, AND STATISTICS}

The following drugs and substances were used: corticosterone 21-acetate (Sigma, St Louis), ( \pm )8-OHDPAT hydrobromide (RBI, Natic, MA), and (S)WAY 100135 (Tocris, $\mathrm{UK})$. All the other reagents and corticosterone antiserum were purchased from Sigma (St Louis, MO).

The data were presented as the mean \pm SEM and were evaluated statistically using STATISTICA software. One-way ANOVA was used to analyze: (1) behavioral experiments showing dose-response of 8-OHDPAT on startle amplitude and calculated \%PPI (dose of 8-OHDPAT as a factor), the results of binding and in situ studies (corticosterone treatment as a factor). Two-way ANOVA was used to analyze: (1) the effect of WAY 100135 on 8-OHDPATinduced disruption of PPI (dose of WAY and dose of 8OHDPAT as factors), (2) the effect of corticosterone on 8OHDPAT-induced disruption of PPI (dose of corticosterone and dose of 8-OHDPAT as factors), (3) the effect of corticosterone on 8-OHDPAT-induced changes in the level of 5-HT and 5-HIAA (dose of corticosterone and dose of 8OHDPAT as factors). Two-way ANOVA for repeated measurements was used to analyze the effects of corticosterone on 8-OHDPAT-induced disruption on PPI calculated from row data (the effect on the amplitude of pulse without and with prepulse), doses of corticosterone and 8-OHDPAT were considered as between-group factors and amplitude of pulse $v s$ amplitude of prepulse + pulse as a withinsubject factor. When significant main effects or interactions were revealed in ANOVA, post hoc comparisons were carried out with Newman-Keuls test. $p<0.05$ was accepted as significant.

\section{RESULTS}

\section{Functional Studies}

Serum corticosterone levels. Corticosterone levels in blood of animals that received different corticosterone treatments are shown in Table 1. Prolonged treatment with corticosterone significantly decreased the weight of adrenal glands and body weight (Table 1).

The effect of 8-OHDPAT on startle amplitude and PPI. The $5-\mathrm{HT}_{1 \mathrm{~A}}$ receptor agonist, 8-OHDPAT (1.25 and $5 \mathrm{mg} /$ $\mathrm{kg}$,) increased the startle amplitude and decreased PPI (Table 2). The dose of $0.2 \mathrm{mg} / \mathrm{kg}$ had no effect on either of these measures (Table 2).

The $5-\mathrm{HT}_{1 \mathrm{~A}}$ receptor antagonist WAY $100135(2.5-20 \mathrm{mg} /$ $\mathrm{kg}$ ), dose dependently attenuated the effects of 8-OHDPAT $(5 \mathrm{mg} / \mathrm{kg})$ on startle amplitude $(\mathrm{F}(1,88)=10.7, p<002)$ and PPI $(\mathrm{F}(1,88)=7.31, p<0.01)$. The dose of $5 \mathrm{mg} / \mathrm{kg}$ of WAY 100135 completely blocked the effects of 8-OHDPAT, similarly as its dose of $20 \mathrm{mg} / \mathrm{kg}$. All used doses of WAY

Table I Effect of Corticosterone on Body Weight and Plasma Corticosterone Levels

\begin{tabular}{|c|c|c|c|c|}
\hline \multirow[b]{2}{*}{ Treatment } & \multicolumn{2}{|c|}{ Body weight (g) } & \multirow{2}{*}{$\begin{array}{c}\text { Plasma } \\
\text { corticosterone } \\
(\mu \mathrm{g} / \mathrm{dl})\end{array}$} & \multirow{2}{*}{$\begin{array}{c}\text { Adrenal } \\
\text { gland weight } \\
(\mathrm{mg} / \mathrm{l} 00 \mathrm{~g})\end{array}$} \\
\hline & Start & End & & \\
\hline Veh & $275 \pm 4.5$ & $308 \pm 5.3$ & $7.89 \pm 1.79$ & $14.5 \pm 0.5$ \\
\hline Cor ac-2h & $293 \pm 2.4$ & $315 \pm 2.5$ & $40.41 \pm 2.09 *$ & $13.6 \pm 1.7$ \\
\hline Cor chr-2h & $288 \pm 6.3$ & $263 \pm 6.3^{*}$ & $63.59 \pm 8.50 *$ & $8.8 \pm 1.4^{*}$ \\
\hline Cor chr-24h & $280 \pm 5.3$ & $246 \pm 8.1 *$ & $22.57 \pm 1.47^{*}$ & $9.4 \pm 0.6 *$ \\
\hline
\end{tabular}

Corticosterone (Cor, $10 \mathrm{mg} / \mathrm{kg}$, s.c.) was administered either at a single dose (ac- $2 \mathrm{~h}$, hormone administration was preceded by 7 -day vehicle injection) or twice daily for 7 days. The body weight was measured before the start of the 7-day treatment and 2 (chr-2h) or $24 \mathrm{~h} \mathrm{(chr-24h)} \mathrm{after} \mathrm{the} \mathrm{end} \mathrm{of} \mathrm{the} \mathrm{treatment.} \mathrm{Plasma} \mathrm{corticosterone} \mathrm{levels}$ $( \pm \mu \mathrm{g} / \mathrm{dl})$ and adrenal gland weight (in $\mathrm{mg} / \mathrm{l} 00 \mathrm{~g}$ of body weight) were measured $2 \mathrm{~h}$ after single administration, or 2 and $24 \mathrm{~h}$ after prolonged treatment with corticosterone. The results are expressed as the mean \pm SEM of IO rats/ group. Asterisks indicate statistical significance. 
100135 did not affect startle amplitude and PPI in vehicletreated animals (Table 3 ).

The effect of corticosterone on 8-OHDPAT-induced inhibition of PPI. As shown in Figure 1a, acute corticosterone treatment had no effect on 8-OHDPAT-induced deficits in sensorimotor gating (amplitude, $\mathrm{F}(2,66)=1.30, p<0.28$; PPI, $\mathrm{F}(2,66)=0.44, p<0.64)$, nor on these measures in control rats (amplitude $\mathrm{F}(1,66)=0.206, p<0.15 ; \quad \mathrm{PPI}$, $\mathrm{F}(1,66)=0.045, p<0.83)$. 8-OHDPAT $(1.25$ and $5 \mathrm{mg} / \mathrm{kg})$ significantly decreased PPI $(\mathrm{F}(2,66)=11.11, p<0.001)$, which resulted from the effect of 8-OHDPAT on the amplitude of startle reflex evoked by acoustic pulse preceded by prepulse $(\mathrm{PP}+\mathrm{P})$.

As shown in Figure $1 \mathrm{~b}$, chronic corticosterone treatment (when measured $2 \mathrm{~h}$ after the last dose) had no effect on PPI in vehicle- and 8-OHDPAT-treated rats $(\mathrm{F}(1,66)=1.944$, $p<0.17$ and $\mathrm{F}(2,66)=0.255, p<0.77$, respectively); however, corticosterone treatment significantly decreased the amplitude of startle reaction $(\mathrm{F}(1,66)=11.039, p<0.001)$ in vehicle- but not 8-OHDPAT-treated rats. 8-OHDPAT $(1.25$ and $5 \mathrm{mg} / \mathrm{kg})$ significantly decreased PPI $(\mathrm{F}(2,66)=16.62$, $p<0.001)$, which resulted from the effect of 8-OHDPAT, on the amplitude of $(\mathrm{PP}+\mathrm{P})$.

As shown in Figure 1c, chronic corticosterone treatment had no effect on PPI in vehicle-treated rats $(\mathrm{F}(2,66)=1.184$,

Table 2 Effect of 8-OHDPAT on the Startle Reaction and PPI in Rats

\begin{tabular}{llc}
\hline Treatment & \multicolumn{1}{c}{$\begin{array}{c}\text { Startle } \\
\text { amplitude }\end{array}$} & \%PPI \\
\hline Vehicle & $361.8 \pm 61.5$ & $56.5 \pm 6.5$ \\
$8-O H D P A T ~(0.2 \mathrm{mg} / \mathrm{kg} \mathrm{s.c.)}$ & $494.1 \pm 70.0$ & $55.6 \pm 6.9$ \\
8 -OHDPAT $(1.25 \mathrm{mg} / \mathrm{kg} \mathrm{s.c.)}$ & $536.4 \pm 80.0 *$ & $18.9 \pm 5.0^{*}$ \\
8 -OHDPAT $(5.0 \mathrm{mg} / \mathrm{kg}$ s.c.) & $589.5 \pm 65.5^{*}$ & $21.6 \pm 4.0^{*}$ \\
\hline
\end{tabular}

8-OHDPAT was given 15 min before the test. The data are presented as the mean amplitude of the startle response produced by an acoustic tone of $120 \mathrm{~dB}$, and as \%PPI. The results are expressed as the mean \pm SEM of 12 rats/group. Asterisks indicate statistically significant $(p<0.05$ at least) alterations of the startle response in 8-OHDPAT-treated rats in comparison with vehicle-injected animals. $p<0.28)$ but attenuated 8-OHDPAT-induced deficits in PPI $(\mathrm{F}(2,66)=3.314, p<0.04)$, when the test was performed $24 \mathrm{~h}$ after the last dose. Analysis of raw data (amplitude of acoustic pulse without and with prepulse) revealed significant interaction between corticosterone treatment, effects of 8-OHDPAT, and type of the applied acoustic stimuli $(\mathrm{F}(2.66)=4.923, p<0.01)$. 8-OHDPAT $(1.25$ and $5 \mathrm{mg} / \mathrm{kg})$ significantly decreased PPI $(\mathrm{F}(2,66)=16.62$, $p<0.001)$, which resulted from the effect of 8 -OHDPAT on the amplitude of $(\mathrm{PP}+\mathrm{P})$ and this effect was attenuated by corticosterone $(\mathrm{F}(1,66)=9.18, p<0.01)$. In this experimental design, corticosterone induced significant difference between an amplitude of the response to pulse $v s$ an amplitude of the response to pulse preceded by prepulse in 8-OHDPAT-treated rats.

The effect of corticosterone on 8-OHDPAT-induced changes in 5-HT and 5-HIAA concentrations. In the hippocampus, single injection of 8 -OHDPAT $(1.25 \mathrm{mg} / \mathrm{kg})$ did not influence 5-HT and 5-HIAA tissue levels, while chronic corticosterone treatment increased the levels of both 5-HT $(\mathrm{F}(1,40)=2.94, p<0.045)$ and its metabolite 5-HIAA $(\mathrm{F}(1,40)=10.46, p<0.0001)$. After the combined treatment, 5-HT level was still increased whereas the level of 5-HIAA was significantly decreased as compared to vehicleand corticosterone-treated animals (Figure 2). 8-OHDPAT decreased significantly $((\mathrm{F}(1,41)=9.02 ; p<0.0001) 5$-HIAA concentration being without effect on 5-HT level in the raphe nuclei. Chronic corticosterone administration evoked similar effect (a decrease in the level of 5-HIAA without any changes in 5-HT), whereas the combined treatment with corticosterone and 8-OHDPAT did not induce greater decreases in 5-HIAA levels than those caused by either drug alone (Figure 2). The effect of 8-OHDPAT on 5-HT metabolism manifested itself also as the decreased 5-HIAA/5-HT ratio observed both in the raphe nuclei $(1.32 \pm 0.07 v s$ $0.98 \pm 0.05^{*}$ in vehicle- and 8-OHDPAT-treated group, respectively) and in the hippocampus (1.06 \pm 0.05 vs $0.81 \pm 0.04^{\star}$, respectively). Corticosterone did not influence 5 -HIAA/5-HT ratio both in the raphe nuclei $(1.16 \pm 0.11$ and $0.81 \pm 0.04$ in vehicle- and 8-OHDPAT-treated rats, respectively) and in the hippocampus (1.04 \pm 0.08 and $0.72 \pm 0.04$ in vehicle- and 8-OHDPAT-treated rats).

Table 3 Effect of WAY I00I35 on the 8-OHDPAT ( $5 \mathrm{mg} / \mathrm{kg}$ s.c.)-Evoked Disruption of PPI of the Acoustic Startle Response in Rats

\begin{tabular}{|c|c|c|c|c|}
\hline & \multicolumn{4}{|c|}{ Treatment } \\
\hline & \multicolumn{2}{|c|}{ Vehicle } & \multicolumn{2}{|c|}{ 8-OHDPAT } \\
\hline & Startle amplitude & \%PPI & Startle amplitude & \%PPI \\
\hline Vehicle & $266.8 \pm 54$ & $46.1 \pm 6.5$ & $497.7 \pm 53^{*}$ & $21.8 \pm 7.0 *$ \\
\hline WAY I00I 35 (2.5 mg/kg s.c.) & $308.6 \pm 57$ & $50.1 \pm 7.9$ & $623.4 \pm 86^{*}$ & $32.9 \pm 7.6$ \\
\hline WAY 100135 (5.0 mg/kg s.c.) & $330.2 \pm 53$ & $45.1 \pm 5.1$ & $327.7 \pm 49^{\#}$ & $40.0 \pm 5.9^{\#}$ \\
\hline WAY I00। 35 (20 mg/kg s.c.) & $268.8 \pm 36$ & $40.0 \pm 5.9$ & $364.7 \pm 62^{\#}$ & $40.1 \pm 3.0^{\#}$ \\
\hline
\end{tabular}



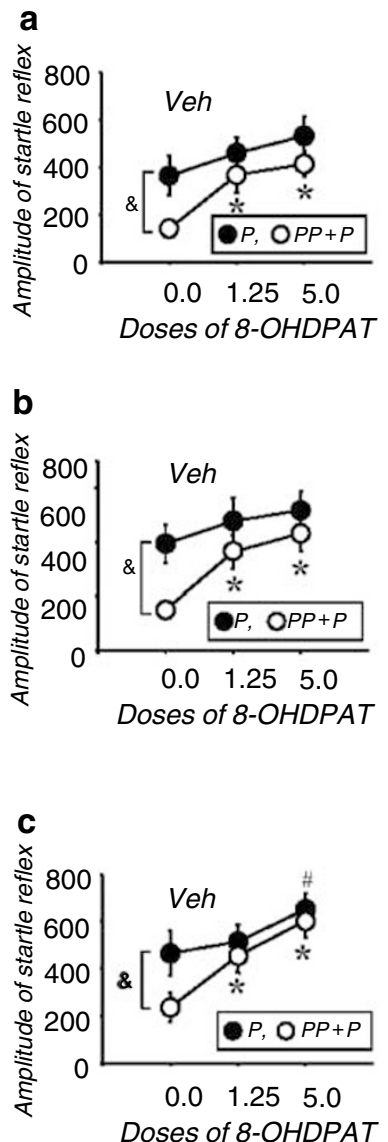
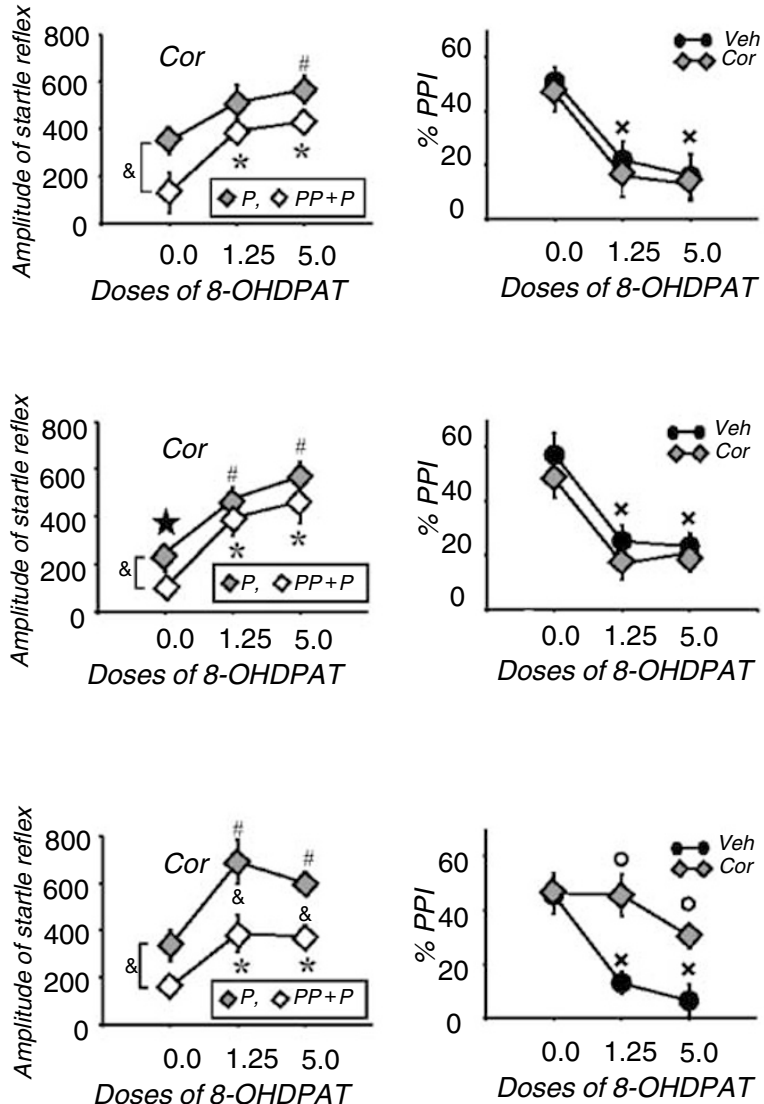

Figure I Effect of corticosterone (Cor) on the amplitude of startle reflex and on the calculated \%PPI induced by 8-OHDPAT (I.25 and 5 mg/kg s.c.). Experiments were performed (a) $2 \mathrm{~h}$ after a single dose of Cor $(10 \mathrm{mg} / \mathrm{kg} \mathrm{s.c.)}$ or (b) $2 \mathrm{~h}$ and (C) $24 \mathrm{~h}$ after the last dose of chronic treatment (Cor, $10 \mathrm{mg} / \mathrm{kg}$ s.c., twice daily, for 7 days). 8-OHDPAT was given 15 min before the test. Left and central panels illustrate the effect of 8-OHDPAT on the amplitude of startle reflex evoked by acoustic pulse (P) and acoustic pulse preceded by prepulse (PP $+\mathrm{P})$ in vehicle (Veh)- and Cor-treated animals, respectively. Right panel illustrates the effect of Cor on 8-OHDPAT-evoked disruption of PPI. The values are the mean \pm SEM of 12 rats/group. " Significant effect on P; *significant effect on PP + P; ${ }^{\star}$ significant effect of corticosterone on P; ${ }^{\star}$ significant difference between P and P+PP; ${ }^{\times}$significant effect of 8-OHDPAT on \%PPI; ' ${ }^{\circ}$ ignificant effect of corticosterone on \%PPI in 8-OHDPAT-treated rats.
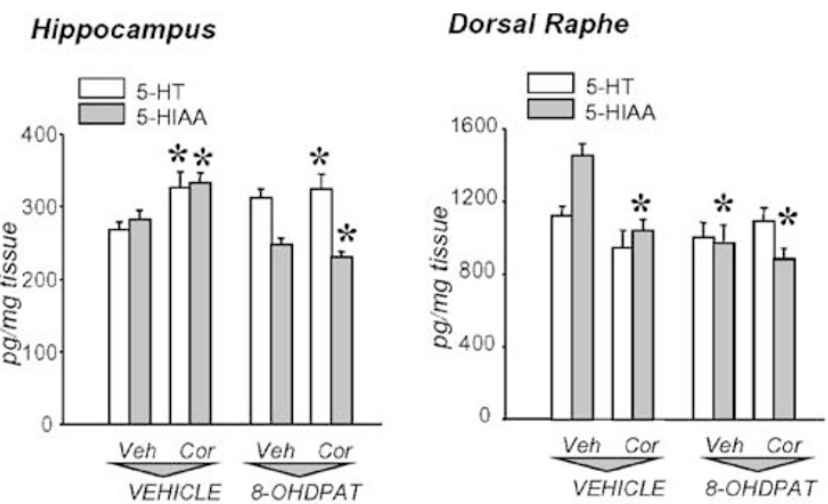

Figure 2 Effect of corticosterone (Cor) on the levels of 5-HT and 5-HIAA in the hippocampus and raphe nuclei of vehicle- or 8-OHDPATtreated rats. Cor was given chronically ( $10 \mathrm{mg} / \mathrm{kg}$ s.c., twice daily for 7 days) and 8-OHDPAT $(1.25 \mathrm{mg} / \mathrm{kg}$, s.c.) was given $23 \mathrm{~h}$ after the last corticosterone dose. The animals were killed I $\mathrm{h}$ after 8 -OHDPAT or respective vehicle treatment. The values are the mean + SEM of 8-16 determinations per group. Asterisks indicate statistical differences in concentrations of 5-HT and 5-HIAA, between vehicle + vehicle- and respective drug-treated rats $(* p<0.05)$

\section{Receptor Studies}

The effect of corticosterone on $5-H T_{1 A}$ receptor binding. The high levels of $5-\mathrm{HT}_{1 \mathrm{~A}}$ binding sites labeled with $\left[{ }^{3} \mathrm{H}\right] 8$ OHDPAT were found in the dorsal raphe nucleus, EC, and hippocampus (Figure 3a,d). The effects of corticosterone on binding at $5-\mathrm{HT}_{1 \mathrm{~A}}$ receptors are shown in Table 4. As revealed by a statistical analysis, the effects of corticosterone on 5- $\mathrm{HT}_{1 \mathrm{~A}}$ receptor binding were time- and brain region-specific. Corticosterone independent of the time of treatment did not modify the $\left[{ }^{3} \mathrm{H}\right] 8$-OHDPAT binding in the raphe nuclei. However, prolonged corticosterone treatment induced significant decreases (23-37\%) in the $\left[{ }^{3} \mathrm{H}\right] 8$-OHDPAT binding in the EC. In the hippocampus, single dose of corticosterone did not influence binding to $5-\mathrm{HT}_{1 \mathrm{~A}}$ receptors in the $\mathrm{CA} 1$ region but increased (16-27\%) this binding in the dentate gyrus (DG), and in the CA3 and CA4 regions. Prolonged treatment with corticosterone, decreased $5-\mathrm{HT}_{1 \mathrm{~A}}$ receptor binding in the DG (18-25\%), and in the ventral part of the CA1 region (17-20\%), while it was without effect in the dorsal part of the CA1 region. 
Table 4 Effect of Corticosterone on the Specific Binding of $\left[{ }^{3} \mathrm{H}\right] 8$-OHDPAT (I.5 nM) to 5-HTIA Receptors in the Rat Brain

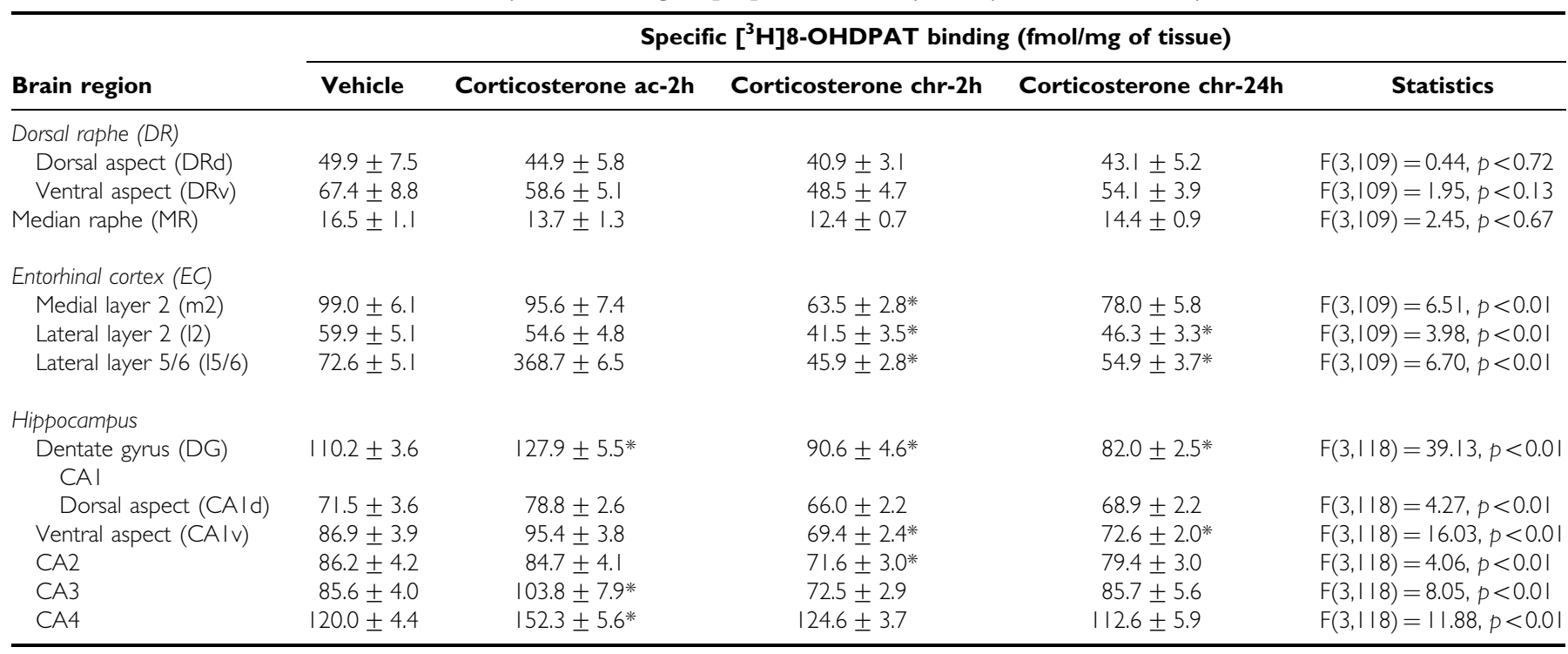

Corticosterone ( $10 \mathrm{mg} / \mathrm{kg}$, s.c.) was administered either at a single dose (hormone administration in this group of rats was preceded by 7 days of vehicle injection) or twice daily for 7 days. The rats were decapitated $2 \mathrm{~h}$ after single administration (ac-2 h), or 2 (chr- $2 \mathrm{~h}$ ) and $24 \mathrm{~h}$ (chr-24h) after prolonged treatment with corticosterone. The results are expressed as the mean \pm SEM for 10-16 rats/group; two brain sections from each rat were used for readings. Asterisks indicate significant differences. Abbreviations given in brackets correspond to Fig. 3.
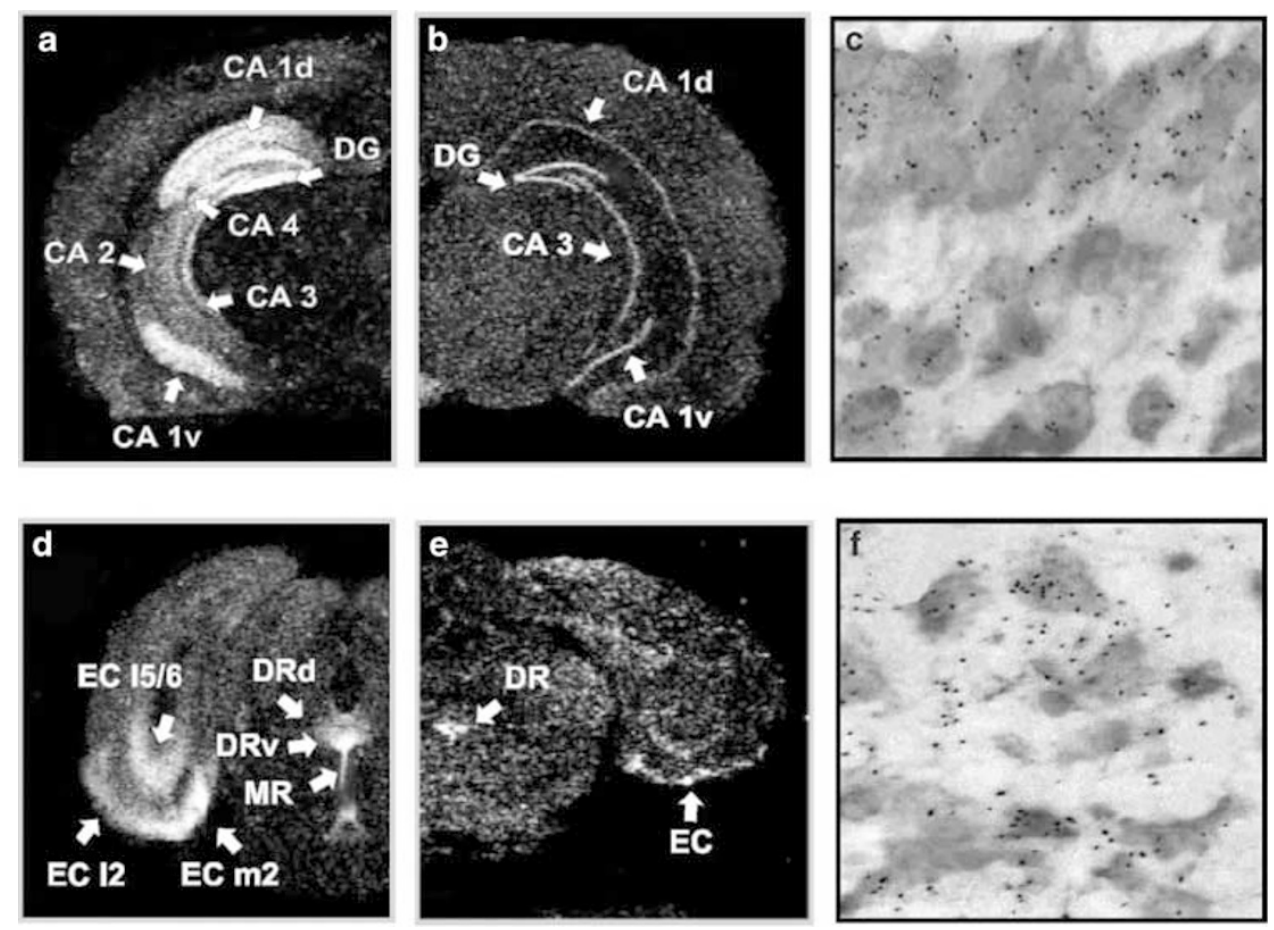

Figure 3 Representative distribution of 5-HTIA receptors and their mRNA in the rat brain sections. Dark-field film autoradiographs of $\left.{ }^{3} \mathrm{H}\right] 8-\mathrm{OHDPAT}$ $(1.5 \mathrm{nM})$ binding to $5-\mathrm{HT}_{\text {IA }}$ receptors at a level of the hippocampus (a) and raphe nuclei (d). Dark-field film autoradiographs of 5-HT IA receptor mRNA, determined by in situ hybridization histochemistry at a level of the hippocampus (b) and dorsal raphe (e). Bright-field photomicrograph (objective $40 \times$ ) of the hippocampus (c) and dorsal raphe ( $f$ ), showing silver grains corresponding to the 5-HTIA receptor mRNA that overlie cell bodies counterstained with cresyl violet. For abbreviations see Table 4.

The effect of corticosterone on $5-H T_{1 A}$ receptor mRNA. Figure $3 \mathrm{~b}, \mathrm{c}, \mathrm{e}, \mathrm{f}$ shows the distribution of $5-\mathrm{HT}_{1 \mathrm{~A}}$ receptor mRNA within the hippocampus, dorsal raphe nucleus, and EC. An analysis of the autoradiographs revealed that in the dorsal raphe nucleus and EC, corticosterone did not induce any change in $5 \mathrm{HT}_{1 \mathrm{~A}}$ receptor mRNA (Table 5) while in the hippocampus only acute corticosterone treatment decreased significantly (18-19\%) the expression of $5 \mathrm{HT}_{1 \mathrm{~A}}$ receptor mRNA in the DG and CA1 region (Table 5). 
Table 5 Effect of Corticosterone on the 5-HTIA Receptor mRNA Expression in the Rat Brain

\begin{tabular}{|c|c|c|c|c|c|}
\hline Brain region & \multicolumn{5}{|c|}{ Optical density (mean \pm SEM in arbitrary units) } \\
\hline Dorsal raphe (DR) & $0.43 \pm 0.04$ & $0.35 \pm 0.02$ & $0.37 \pm 0.02$ & $0.40 \pm 0.03$ & $F(3,29)=1.49, p<0.20$ \\
\hline $\begin{array}{l}\text { Dentate gyrus (DG) } \\
\text { CAI }\end{array}$ & $0.49 \pm 0.02$ & $0.40 \pm 0.02 *$ & $0.52 \pm 0.02$ & $0.51 \pm 0.02$ & $F(3,62)=4.11, p<0.01$ \\
\hline CA3 & $0.43 \pm 0.01$ & $0.37 \pm 0.02$ & $0.41 \pm 0.02$ & $0.45 \pm 0.01$ & $F(3,62)=3.38, p<0.05$ \\
\hline
\end{tabular}

Corticosterone ( $10 \mathrm{mg} / \mathrm{kg}$, s.c.) was administered either at a single dose (hormone administration in this group of rats was preceded by 7 days of vehicle injection) or twice daily for 7 days. The rats were decapitated $2 \mathrm{~h}$ after single administration (ac- $2 \mathrm{~h}$ ), or 2 (chr-2 h) and $24 \mathrm{~h}$ (chr-24 h) after prolonged treatment with corticosterone. The results are expressed as the mean \pm SEM for 7-12 rats/group; two brain sections from each rat were used for readings. Asterisks indicate the significant differences. Abbreviations given in brackets correspond to Figure 3. For abbreviations see Table 4.

\section{DISCUSSION}

Our experiments revealed that neither prolonged nor acute treatment with corticosterone was able to influence the PPI in control animals. However, prolonged treatment with corticosterone, which produced persistent elevation of its blood levels comparable to those observed in severe to moderate stress (de Kloet et al, 1990; Raghupathi and McGonigle, 1997), attenuated the disruptive effects of 8-OHDPAT on PPI, which may suggest that corticosterone attenuated the function of 5- $\mathrm{HT}_{1 \mathrm{~A}}$ receptors. The effect of 8OHDPAT on the PPI resulted from stimulation of $5-\mathrm{HT}_{1 \mathrm{~A}}$ receptors (see also Sipes and Geyer, 1995) since it was completely abolished by the dose of WAY $100135(5 \mathrm{mg} / \mathrm{kg})$ considered to be selective for blocking $5-\mathrm{HT}_{1 \mathrm{~A}}$ receptors (Cliffe et al, 1993; Assie and Koek, 1996).

Further, we found that corticosterone given repeatedly decreased the amplitude of startle reaction, and this effect was negatively correlated with blood hormone levels. It was observed only shortly $(2 \mathrm{~h})$ after the last dose of prolonged treatment $(24 \mathrm{~h}$ after the treatment the effect was no longer observed). Similar results were obtained by Glowa et al (1992) who also found an inverse relation between the startle amplitude and circulating corticosterone levels. However, it seems that corticosterone-induced attenuation of the disruptive effects of 8-OHDPAT on PPI did not result from its effects on startle, since the effects of corticosterone on startle amplitude were seen only in vehicle- and not 8OHDPAT-treated animals. Moreover, the attenuation of the disruptive effects of 8-OHDPAT on PPI was observed at the time when the effect of corticosterone on startle amplitude already disappeared ( $24 \mathrm{~h}$ after last dose).

The mechanism by which corticosterone attenuated the responsiveness to 8-OHDPAT in PPI test is not known. As it was shown by Sipes and Geyer (1995), 8-OHDPAT injected directly into the raphe nuclei diminished PPI, which suggested that the somatodendritic $5-\mathrm{HT}_{1 \mathrm{~A}}$ autoreceptors and the ability of 8-OHDPAT to decrease the activity of serotonergic neurons (Hjorth and Sharp, 1991; Sipes and Geyer, 1995; Fletcher et al, 2001; Prinssen et al, 2002) in raphe nuclei played a role in the 8-OHDPAT-induced disruption of PPI. The above arguments might have indicated that corticosterone-induced changes in 5-HT metabolism had contributed to this effect. However, we found that in the raphe nuclei both chronic treatment with corticosterone and injection of 8-OHDPAT induced decreases in 5-HT metabolism (a decrease in 5-HIAA level without changes in 5-HT level), whereas 8-OHDPAT did not induce further decreases in corticosterone-treated animals. In the hippocampus, corticosterone increased metabolism of 5-HT, elevating both the level of 5-HT and 5-HIAA, which is in line with the findings showing that glucocorticoids increase the activity of tryptophan hydroxylase, a rate-limiting enzyme in 5-HT synthesis (Singh et al, 1990) in a tissue-specific manner (Clark and Russo, 1997). 8OHDPAT did not influence 5-HT and 5-HIAA levels in the hippocampus; however, it significantly decreased 5-HIAA/ 5-HT ratio (considered to reflect the decreased 5-HT turnover), and this effect of 8-OHDPAT was not changed by corticosterone. All these data together show that both corticosterone and 8-OHDPAT influence 5-HT metabolism; however, the effects of 8-OHDPAT were not attenuated by corticosterone; moreover, both drugs induced similar effects on 5-HT activity in the raphe nuclei. Therefore, the effect of corticosterone on 5-HT metabolism and somatodendritic autoreceptors is not likely to be engaged in the observed corticosterone-induced attenuation of the behavioral effects of 8-OHDPAT on PPI. This conclusion was supported further by receptor studies that showed no effect of corticosterone on $5-\mathrm{HT}_{1 \mathrm{~A}}$ receptor binding and expression in the raphe nuclei.

However, we found that chronic treatment with corticosterone decreased $5-\mathrm{HT}_{1 \mathrm{~A}}$ receptor binding in the $\mathrm{DG}$ and in the ventral part of CA1 region of the hippocampus, as well as in the EC. Interestingly, these brain structures have been suggested to be implicated in the regulation of PPI (Bast et al, 2001; Swerdlow et al, 2001a,b). It is clear from our previous studies that the $5-\mathrm{HT}_{1 \mathrm{~A}}$ receptors are important for the modulation of PPI disrupted not only by agonists of these receptors but also by NMDA receptor antagonists (Wedzony et al, 1997, 2000). The detrimental effect of MK-801 on PPI was blocked by $5-\mathrm{HT}_{1 \mathrm{~A}}$ receptor antagonist WAY 100135 (Wedzony et al, 2000). Moreover, MK-801 used at doses that disrupted PPI in rats increased $5-\mathrm{HT}_{1 \mathrm{~A}}$ receptor binding, and this effect was especially potent and long lasting in the EC and ventral part of the hippocampus (Wedzony et al, 1997). Thus, it seems reasonable to suggest that region-specific decreases in 
$5-\mathrm{HT}_{1 \mathrm{~A}}$ receptor binding may contribute to the corticosterone-induced attenuation of effects of 8-OHDPAT on PPI. Azmitia et al (1996) have shown that, in the hippocampus and cerebral cortex, the $5-\mathrm{HT}_{1 \mathrm{~A}}$ receptor protein is located on initial segments of axons of pyramidal cells; therefore, these receptors are in strategic position for the regulation of cell excitability and output signal propagation. In line with this assumption, we observed decreased electrophysiological responsiveness to 8-OHPAT in CA1 hippocampal neurons of the corticosterone-treated rats (Czyrak et al, 2002).

Corticosterone induced downregulation of the $5-\mathrm{HT}_{1 \mathrm{~A}}$ receptors after prolonged, but not after single, administration, whereas only single injection of corticosterone was capable of decreasing the $5-\mathrm{HT}_{1 \mathrm{~A}}$ receptor $\mathrm{mRNA}$ in the hippocampus. These results suggest that acute changes in plasma corticosterone are very rapidly accompanied by decreases in $5-\mathrm{HT}_{1 \mathrm{~A}}$ receptor mRNA, whereas alterations in the receptor protein levels occur much more slowly. That is not surprising in the light of the results (Pinto and Battaglia, 1994) showing that a half-life of the $5-\mathrm{HT}_{1 \mathrm{~A}}$ receptor protein is ca 5 days. Our results, presenting decreased expression of $5-\mathrm{HT}_{1 \mathrm{~A}}$ receptors after corticosterone treatment, are generally in line with many other studies (Mendelson and McEwen, 1992a, b; Meijer et al, 1997; Takao et al, 1997; Lopez et al, 1998, 1999; Karten et al, 1999), although the lack of changes particularly in the CA1 region of hippocampus was also reported (Mendelson and McEwen, 1992a, b; Holmes et al, 1995; Fernandes et al, 1997). This inconsistency may be explained by our observation that the effect of corticosterone on $5-\mathrm{HT}_{1 \mathrm{~A}}$ receptor binding differs from dorsal to ventral part of CA1 region, whereas the studies cited above did not differentiate parts of this region.

Behavioral responsiveness to 8-OHDPAT was attenuated in rats that received prolonged, but not acute, treatment with corticosterone, which suggests that the effect of corticosterone developed with time as an adaptive decrease in $5-\mathrm{HT}_{1 \mathrm{~A}}$ receptor functioning. The effects of corticosterone on hyperpolarization induced by 8-OHDPAT in the hippocampus (Bijak et al, 2001; Czyrak et al, 2002) as well as on cyclic AMP generating system (Czyrak, 1996), to which $5-\mathrm{HT}_{1 \mathrm{~A}}$ receptor is negatively coupled, were also observed only after prolonged treatment and persisted up to $48 \mathrm{~h}$ after the treatment. Correspondingly, the decreases in $5-\mathrm{HT}_{1 \mathrm{~A}}$ receptor binding were also observed after chronic treatment with corticosterone. However, receptor changes were observed both 2 and $24 \mathrm{~h}$ after the last treatment, whereas functional changes appeared $24 \mathrm{~h}$ after the last dose. This discrepancy is difficult to interpret. Possibly, the high corticosterone level reached after hormone injection influenced not only $5-\mathrm{HT}_{1 \mathrm{~A}}$ receptor binding but also other intracellular processes ( $G$ proteins, regulators of $\mathrm{G}$ protein signaling, potassium channels) distal to receptor protein (Okuhara et al, 1997; Ni et al, 1999; Muma and Beck, 1999; Dwivedi and Pandey, 2000) giving the above final behavioral effect.

Summing up, we have shown that prolonged rise in corticosterone level induced functional desensitization of 5$\mathrm{HT}_{1 \mathrm{~A}}$ receptors measured as an attenuation of 8-OHDPATinduced disruption of PPI, which was paralleled by the downregulation of the $5-\mathrm{HT}_{1 \mathrm{~A}}$ receptors in the brain structures (ventral hippocampus and EC) shown to be engaged in the regulation of PPI. The results suggest that region-specific changes in $5-\mathrm{HT}_{1 \mathrm{~A}}$ receptor density may be responsible for the observed desensitization of the effects of 8-OHDPAT. Although the corticosterone-evoked attenuation of the effects of 8-OHDPAT on PPI indicates general functional downregulation of $5-\mathrm{HT}_{1 \mathrm{~A}}$ receptors rather than modulation of any specific deficit, a question arises whether this apparent beneficial effect of corticosterone might reflect its putative effectiveness in preventing at least some symptoms of illnesses during which sensorimotor gating is disordered.

\section{NOTE TO READERS}

It is with deep sorrow that we would like to inform you that Anna Czyrak passed away during the final stages of sending this paper to press. Her unexpected death is a painful and irreparable loss for us. Her passing has left us bereft of an open-hearted, open-minded person, distinguished scientist and our unforgettable friend.

\section{REFERENCES}

Ahima RS, Tagoe CN, Harlan RE (1992). Type II corticosteroid receptor-like immunoreactivity in the rat cerebellar cortex: differential regulation by corticosterone. Neuroendocrinology 55: 683-694.

Assie MB, Koek W (1996). Effects of 5-HT1A receptor antagonists on hippocampal 5-hydroxytryptamine levels: (S)-WAY100135, but not WAY100635, has partial agonist properties. Eur J Pharmacol 304: 15-21.

Azmitia EC, Gannon PJ, Kheck NM, Whitaker-Azmitia PM (1996). Cellular localization of the 5-HT1A receptor in primate brain neurons and glial cells. Neuropsychopharmacology 14: 35-46.

Bantick RA, Deakin JF, Grasby PM (2001). The 5-HT1A receptor in schizophrenia: a promising target for novel atypical neuroleptics? J Psychopharmacol 15: 37-46.

Bast T, Zhang WN, Feldon J (2001). Hyperactivity, decreased startle reactivity, and disrupted prepulse inhibition following disinhibition of the rat ventral hippocampus by the GABA(A) receptor antagonist picrotoxin. Psychopharmacology (Berl) 156: 225-233.

Bijak M, Zahorodna A, Tokarski K (2001). Opposite effects of antidepressants and corticosterone on the sensitivity of hippocampal CA1 neurons to 5-HT1A and 5-HT4 receptor activation. Naunyn Schmiedebergs Arch Pharmacol 363: 491-498.

Braff DL, Geyer MA, Swerdlow NR (2001). Human studies of prepulse inhibition of startle: normal subjects, patient groups, and pharmacological studies. Psychopharmacology (Berl) 156: 234-258.

Braff DL, Grillon C, Geyer MA (1992). Gating and habituation of the startle reflex in schizophrenic patients. Arch Gen Psychiatry 49: 206-215.

Burnet PW, Eastwood SL, Harrison PJ (1996). 5-HT1A and 5-HT2A receptor mRNAs and binding site densities are differentially altered in schizophrenia. Neuropsychopharmacology 15: 442-455.

Chalmers DT, Lopez JF, Vazquez DM, Akil H, Watson SJ (1994). Regulation of hippocampal 5-HT1A receptor gene expression by dexamethasone. Neuropsychopharmacology 10: 215-222.

Clark MS, Russo AF (1997). Tissue-specific glucocorticoid regulation of tryptophan hydroxylase mRNA levels. Mol Brain Res 48: 346-354.

Cliffe IA, Brightwell CI, Fletcher A, Forster EA, Mansell HL, Reilly $Y$ et al (1993). (S)-tert-butyl-3-(4-(2-methoxyphenyl)-piperazin1-yl)-2-phenylpropanamid e [(S)-WAY-100135]: a selective 
antagonist at presynaptic and postsynaptic 5-HT1A receptors. $J$ Med Chem 36: 1509-1510.

Conti LH, Murry JD, Ruiz MA, Printz MP (2002). Effects of corticotropin-releasing factor on prepulse inhibition of the acoustic startle response in two rat strains. Psychopharmacology (Berl) 161: 296-303.

Czyrak A (1996). Modulation of the forskolin-induced cyclic AMP accumulation by corticosterone. Pol J Pharmacol 48: 595-599.

Czyrak A, Makowiak M, Chocyk A, Fijał K, Tokarski K, Bijak M et al (2002). Prolonged corticosterone treatment alters the responsiveness of $5-\mathrm{HT} 1 \mathrm{~A}$ receptors to $8-\mathrm{OH}-\mathrm{DPAT}$ in rat CA1 hippocampal neurons. Naunyn-Schmiedeberg's Arch Pharmacol 366: 357-367.

de Kloet ER, Reul JM, Sutanto W (1990). Corticosteroids and the brain. J Steroid Biochem Mol Biol 37: 387-394.

Dwivedi Y, Pandey GN (2000). Adrenal glucocorticoids modulate ?(3)HCyclic AMP binding to protein kinase A (PKA), cyclic AMP-dependent PKA activity, and protein levels of selective regulatory and catalytic subunit isoforms of PKA in rat brain. $J$ Pharmacol Exp Ther 294: 103-116.

Ellenbroek BA, van den Kroonenberg PT, Cools AR (1998). The effects of an early stressful life event on sensorimotor gating in adult rats. Schizophr Res 30: 251-260.

Faraday MM, O’Donoghue VA, Grunberg NE (1999). Effects of nicotine and stress on startle amplitude and sensory gating depend on rat strain and sex. Pharmacol Biochem Behav 62: 273-284.

Fendt M, Li L, Yeomans JS (2001). Brain stem circuits mediating prepulse inhibition of the startle reflex. Psychopharmacology (Berl) 156: 216-224.

Fernandes C, McKittrick CR, File SE, McEwen BS (1997). Decreased 5-HT1A and increased 5-HT2A receptor binding after chronic corticosterone associated with a behavioural indication of depression but not anxiety. Psychoneuroendocrinology 22: 477-491.

Fletcher PJ, Selhi ZF, Azampanah A, Sills TL (2001). Reduced brain serotonin activity disrupts prepulse inhibition of the acoustic startle reflex. Effects of 5,7-dihydroxytryptamine and p-chlorophenylalanine. Neuropsychopharmacology 24: 399-409.

Geyer MA, Krebs-Thomson K, Braff DL, Swerdlow NR (2001). Pharmacological studies of prepulse inhibition models of sensorimotor gating deficits in schizophrenia: a decade in review. Psychopharmacology (Berl) 156: 117-154.

Geyer MA, Swerdlow NR, Mansbach RS, Braff DL (1990). Startle response models of sensorimotor gating and habituation deficits in schizophrenia. Brain Res Bull 25: 485-498.

Geyer MA, Wilkinson LS, Humby T, Robbins TW (1993). Isolation rearing of rats produces a deficit in prepulse inhibition of acoustic startle similar to that in schizophrenia. Biol Psychiatry 34: 361-372.

Glowa JR, Geyer MA, Gold PW, Sternberg EM (1992). Differential startle amplitude and corticosterone response in rats. Neuroendocrinology 56: 719-723.

Grillon C, Davis M (1997). Effects of stress and shock anticipation on prepulse inhibition of the startle reflex. Psychophysiology 34: 511-517.

Harfstrand A, Fuxe K, Cintra A, Agnati LF, Zini I, Wikstrom AC et al (1986). Glucocorticoid receptor immunoreactivity in monoaminergic neurons of rat brain. Proc Natl Acad Sci USA 83: 9779-9783.

Harrison PJ (1999). Neurochemical alterations in schizophrenia affecting the putative receptor targets of atypical antipsychotics focus on dopamine (D1, D3, D4) and 5-HT2a receptors. $\mathrm{Br} J$ Psychiatry 294(Suppl): 12-22.

Hjorth S, Sharp T (1991). Effect of the 5-HT1A receptor agonist 8OH-DPAT on the release of 5-HT in dorsal and median rapheinnervated rat brain regions as measured by in vivo microdialysis. Life Sci 48: 1779-1786.
Holmes MC, Yau JL, French KL, Seckl JR (1995). The effect of adrenalectomy on 5-hydroxytryptamine and corticosteroid receptor subtype messenger RNA expression in rat hippocampus. Neuroscience 64: 327-337.

Joels M, de Kloet ER (1992). Coordinative mineralocorticoid and glucocorticoid receptor-mediated control of responses to serotonin in rat hippocampus. Neuroendocrinology 55: 344-350.

Karten YJ, Nair SM, van Essen L, Sibug R, Joels M (1999). Longterm exposure to high corticosterone levels attenuates serotonin responses in rat hippocampal CA1 neurons. Proc Natl Acad Sci USA 96: 13456-13461.

Koch M (1999). The neurobiology of startle. Prog Neurobiol 59: 107-128.

Kuroda Y, Watanabe Y, Albeck DS, Hastings NB, McEwen BS (1994). Effects of adrenalectomy and type I or type II glucocorticoid receptor activation on 5-HT1A and 5-HT2 receptor binding and 5-HT transporter mRNA expression in rat brain. Brain Res 648: 157-161.

Liao B, Miesak B, Azmitia EC (1993). Loss of 5-HT1A receptor mRNA in the dentate gyrus of the long-term adrenalectomized rats and rapid reversal by dexamethasone. Mol Brain Res 19: $328-332$.

Lopez JF, Chalmers DT, Little KY, Watson SJ (1998). A.E. Bennett Research Award. Regulation of serotonin1A, glucocorticoid, and mineralocorticoid receptor in rat and human hippocampus: implications for the neurobiology of depression. Biol Psychiatry 43: $547-573$.

Lopez JF, Liberzon I, Vazquez DM, Young EA, Watson SJ (1999). Serotonin 1A receptor messenger RNA regulation in the hippocampus after acute stress. Biol Psychiatry 45: 934-937.

McEwen BS, Weiss JM, Schwartz LS (1968). Selective retention of corticosterone by limbic structures in rat brain. Nature 220: 911-912.

Meijer OC, Van Oosten RV, de Kloet ER (1997). Elevated basal trough levels of corticosterone suppress hippocampal 5hydroxytryptamine(1A) receptor expression in adrenally intact rats: implication for the pathogenesis of depression. Neuroscience 80: 419-426.

Mendelson SD, McEwen BS (1992a). Autoradiographic analyses of the effects of adrenalectomy and corticosterone on 5-HT1A and 5-HT1B receptors in the dorsal hippocampus and cortex of the rat. Neuroendocrinology 55: 444-450.

Mendelson SD, McEwen BS (1992b). Quantitative autoradiographic analyses of the time course and reversibility of corticosteroneinduced decreases in binding at 5-HT1A receptors in rat forebrain. Neuroendocrinology 56: 881-888.

Mueller NK, Beck SG (2000). Corticosteroids alter the 5-HT(1A) receptor-mediated response in CA1 hippocampal pyramidal cells. Neuropsychopharmacology 23: 419-427.

Muma NA, Beck SG (1999). Corticosteroids alter G protein inwardly rectifying potassium channels protein levels in hippocampal subfields. Brain Res 839: 331-335.

Ni YG, Gold SJ, Iredale PA, Terwilliger RZ, Duman RS, Nestler EJ (1999). Region-specific regulation of RGS4 (regulator of Gprotein-signaling protein type 4) in brain by stress and glucocorticoids: in vivo and in vitro studies. J Neurosci 19: 3674-3680.

Okuhara DY, Beck SG, Muma NA (1997). Corticosterone alters G protein alpha-subunit levels in the rat hippocampus. Brain Res 745: 144-151.

Paxinos G, Watson C (1998). The Rat Brain in Stereotaxic Coordinates, 4th edn. Academic Press: San Diego.

Pinto W, Battaglia G (1994). Comparative recovery kinetics of 5hydroxytryptamine $1 \mathrm{~A}, 1 \mathrm{~B}$, and $2 \mathrm{~A}$ receptor subtypes in rat cortex after receptor inactivation: evidence for differences in receptor production and degradation. Mol Pharmacol 46: 1111-1119. 
Prinssen EP, Assie MB, Koek W, Kleven MS (2002). Depletion of 5-HT disrupts prepulse inhibition in rats: dependence on the magnitude of depletion, and reversal by a 5-HT precursor. Neuropsychopharmacology 26: 340-347.

Przegalinski E, Budziszewska B, Grochmal A (1992). Effect of adenosine analogues on plasma corticosterone concentration in rats. Acta Endocrinol (Copenh) 27: 471-475.

Raghupathi RK, McGonigle P (1997). Differential effects of three acute stressors on the serotonin 5-HT1A receptor system in rat brain. Neuroendocrinology 65: 246-258.

Rigdon GC, Weatherspoon JK (1992). 5-Hydroxytryptamine 1a receptor agonists block prepulse inhibition of acoustic startle reflex. J Pharmacol Exp Ther 263: 486-493.

Singh VB, Corley KC, Phan TH, Boadle-Biber MC (1990). Increases in the activity of tryptophan hydroxylase from rat cortex and midbrain in response to acute or repeated sound stress are blocked by adrenalectomy and restored by dexamethasone treatment. Brain Res 516: 66-76.

Sipes TA, Geyer MA (1994). Multiple serotonin receptor subtypes modulate prepulse inhibition of the startle response in rats. Neuropharmacology 33: 441-448.

Sipes TA, Geyer MA (1995). 8-OH-DPAT disruption of prepulse inhibition in rats: reversal with (+)WAY 100,135 and localization of site of action. Psychopharmacology (Berl) 117: 41-48.

Sipos ML, Bauman RA, Widholm JJ, Kant GJ (2000). Behavioral effects Of 8-OH-DPAT in chronically stressed male and female rats. Pharmacol Biochem Behav 66: 403-411.

Swerdlow NR, Geyer MA, Braff DL (2001a). Neural circuit regulation of prepulse inhibition of startle in the rat: current knowledge and future challenges. Psychopharmacology (Berl) 156: 194-215.

Swerdlow NR, Hanlon FM, Henning L, Kim YK, Gaudet I, Halim ND (2001b). Regulation of sensorimotor gating in rats by hippocampal NMDA: anatomical localization. Brain Res 898: 195-203.

Takao K, Nagatani T, Kitamura Y, Yamawaki S (1997). Effects of corticosterone on 5-HT1A and 5-HT2 receptor binding and on the receptor-mediated behavioral responses of rats. Eur J Pharmacol 333: 123-128.

Tejani-Butt SM, Labow DM (1994). Time course of the effects of adrenalectomy and corticosterone replacement on 5-HT1A receptors and 5-HT uptake sites in the hippocampus and dorsal raphe nucleus of the rat brain: an autoradiographic analysis. Psychopharmacology (Berl) 113: 481-486.

Walder DJ, Walker EF, Lewine RJ (2000). Cognitive functioning, cortisol release, and symptom severity in patients with schizophrenia. Biol Psychiatry 48: 1121-1132.

Walker EF, Diforio D (1997). Schizophrenia: a neural diathesisstress model. Psychol Rev 104: 667-685.

Wedzony K, Golembiowska K, Zazula M (1994). Differential effects of CGP 37849 and MK-801, competitive and noncompetitive NMDA antagonists, with respect to the modulation of sensorimotor gating and dopamine outflow in the prefrontal cortex of rats. Naunyn Schmiedeberg's Arch Pharmacol 350: $555-562$.

Wedzony K, Mackowiak M, Czyrak A, Fijal K, Michalska B (1997). Single doses of MK-801, a non-competitive antagonist of NMDA receptors, increase the number of 5-HT1A serotonin receptors in the rat brain. Brain Res 756: 84-91.

Wedzony K, Mackowiak M, Zajaczkowski W, Fijal K, Chocyk A, Czyrak A (2000). WAY 100135, an antagonist of 5-HT1A serotonin receptors, attenuates psychotomimetic effects of MK801. Neuropsychopharmacology 23: 547-559.

Weiss IC, Feldon J (2001). Environmental animal models for sensorimotor gating deficiencies in schizophrenia: a review. Psychopharmacology (Berl) 156: 305-326. 